\title{
Democracy and Incumbent Political Power Struggle for the Indonesian Regional Head Election
}

\author{
Ilham Yamin Ismail ${ }^{1}$, Rizal Mohd Yakoop ${ }^{1}$, Kamaruzaman Jusoff ${ }^{2}$, Muhammad Febriansyah ${ }^{1} \&$ Nurwati $^{3}$ \\ ${ }^{1}$ Faculty of Social Science and Humanities, Universiti Kebangsaan Malaysia, Selangor, Malaysia \\ ${ }^{2}$ Faculty of Forestry, Universiti Putra Malaysia, Selangor, Malaysia \\ ${ }^{3}$ Faculty of Economics, Universitas Halu Oleo, Sulawesi, Indonesia \\ Correspondence: Ilham Yamin Ismail, Faculty of Social Science and Humanities, Universiti Kebangsaan \\ Malaysia, 43600 Bangi, Selangor, Malaysia. E-mail: ilham_mei@yahoo.com
}

\author{
Received: February 24, 2014 Accepted: April 22, $2014 \quad$ Online Published: April 29, 2014 \\ doi:10.5539/ass.v10n10p212 URL: http://dx.doi.org/10.5539/ass.v10n10p212
}

\begin{abstract}
The objective of this paper is to investigate the process of the local political practices that generate unflourishing democracy in power struggle of the incumbent. It addresses the political power of the incumbent in the domain of local democracy in the reform era of Takalar local election in 2007. The weak function of Election Supervisory Committee (PANWASLU) was highlighted and the position of the incumbent to remain in power struggle was identified. This paper reveals the causes of delays in the formation of Election Supervisory Committee, the dependency of the district election committee, and the utilization of the position and role of bureaucrats with the incumbent winning team. It can be implied that the direct election at the local level has not been in accordance with the norm of democracy. This paper uses a qualitative approach through case studies of the 2007 local elections in Takalar South Sulawesi, Indonesia. The samples were selected using a purposive sampling technique. The research was conducted in February, June, July and August 2012. Further research should be conducted on the incumbent whether to retain his position or otherwise in the next upcoming Regional Head Election.
\end{abstract}

Keywords: democracy, local election, political party, incumbent, election supervisory committee

\section{Introduction}

Political power through the practice of local democracy generates problems. Thus, this paper explains the position of the incumbent in the context of case studies of regional head elections. Before further discussion on this matter, the practices of incumbent power struggles that have been studied by many scholars previously were looked into. The study of democracy and political power by the Gordon and Landa (2009) found that the incumbent wants to fight back due to availability of resources, such as holding or so called discount campaign finance campaigns which are not available for the opponents. The support of the incumbent is useful to build the relationships in order to influence the interest groups or elites within a district or a county. Besides La Venia (2011) stated that as holders of political power, the incumbent has a lot of advantages to advance to the next general election. This reduces the impact of democratic values in the electoral process which can be considered as unfair to the challenger. Furthermore, the political parties were supposed to be able to win the power through elections.

After reviewing various works and studies, the position of the incumbent to the local level such as district or city state constitutional guarantees are given to officials who have the power to fight in the second period. The "room" to move forward in the next period is literally called the incumbent. Why would this be so critical and important to this study? This question is so important in order to look at the local level democratic arena that has been contaminated by various political practices that are used to achieve goals, particularly involving the incumbent. The intervention of political power debilitates the ggeneral election supervisory committee. Power control, played by civil society seemed unstoppable with the swift sway incumbent power forward.

Democracy through direct election (PILKADA) marked the transition era of the new order from a centralized to decentralize process through local political level. Erb and Priyambudi (2009) stated that Indonesia, in 2004 has the experience for the first time to directly elect their national leaders and this is the initial momentum of democratization in Indonesia. The local Chief Election (Election) is a new aspect of democracy that is subsequently a transition to democracy. Democratization is the power of local communities to make decisions 
for the benefit of local and regional leaders through direct election. However, the domain of democracy in the local level has generated democracy decay everywhere. The first direct election in Indonesia began in June 2005. Up to the present, problems always arise every time election is held in Indonesia. Crouch (2010) has revealed some cases of election. In one year of enactment of the elections, there have been investigation of cases on seven governors, 45 regents or mayors and their representatives and some of them have been sentenced in early 2006 . The results of the study of elections by Mietzner (2007) in Erb and Priyambudi (2009) reported that decentralization generates thugs (gangsters), money politics and corruption at local level. Accordingly, through a Singapore undergraduate organized Workshop on Elections in May 2006, Singaporeans, Australians, British and Indonesians concluded many pessimistic views through direct election. This paper therefore analysis the incumbent political power through case studies of the 2007 election Takalar which is considered not to foster democracy. The interventions of the regime's political power of incumbent election were revealed.

\section{Methods}

This paper uses a qualitative approach through case studies of the 2007 local elections in Takalar South Sulawesi, Indonesia. The samples were selected using a purposive sampling technique. The research was conducted in February, June, July and August 2012. The data were collected by means of observation and in-depth interviews. Further analysis of this article involves the theoretical concepts of democracy and the concept of the power of the incumbent.

\section{Results}

\subsection{The Concept of Democracy and the Power of the Incumbent}

According to Schumpeter (2003, p. 13), the conceptualization of democracy can be understood with such a statement as follows:

"Is arguing for a minimalist conceptualization of democracy and that of civil rights or 'abiding by the will of the people directly' is not necessary for a government to be a democracy and function accordingly. Democracy is merely a method of, and the institutions used in, choosing a government through competitive elections. Through these elections, representatives are chosen, and the common good is derived from the tally of votes. It is the competition for representation that drives democracy and through this competition that the benefits that citizens acquire from democracy over other forms of government manifest themselves."

In line with this view, voters choose their representatives through democratic methods of direct elections so as to create the government that serves the people. However, before the creation of this government there should be terms and conditions apply. This is called by Schumpeter in terms of democracy as a method of selection based on voter rights to produce a choice, manifested into a form of government. Democracy rests researchers thought that Schumpeter dissected by Bunce (2000) produced about pre-conditions to consolidate democracy as mentioned:

"... how governance infrastructure and democracy interact with one another, while jointly affecting states, has to do with the possibility that governance infrastructure is a pre-condition for a consolidated democracy".

Based on a range of views on the application of the concept of degree of democracy as a political system, Baird (2012) invented the concept of governance infrastructure that consists of four elements; namely: (i) government effectiveness, (ii) regulatory quality, (iii) the rule of law, (iv) control of corruption. Baird's view is a foothold that reveals how local democracy through the electoral arena Takalar 2007 by the incumbent powers through the use of sound electoral commissions, electoral supervisory postponement so that they can return to power. Another argument about the concept of democracy as a political system according to Larry et al. (1990) as cited in Vanhanen (1997) defined democracy as a system of government:

"That meets three essential conditions: meaningful and extensive competition among individuals and organized groups (especially political parties) for all effective positions of government power, at regular intervals and excluding the use of power, at regular intervals and excluding the use of force; a highly inclusive level of political participation in the selection of the leaders and policies, at least through regular and fair elections, such that no major (adult) social group is excluded; and a level of civil and political liberties-freedom expressions, the press freedom, freedom to form and join Organizations-sufficient to Ensure the integrity of political competition and participation."

By revealing the findings of this study is the weaknesses of electoral supervisory through the establishment of PANWASLU postponement. Secondly, through the intervention by utilizing the power of the incumbent as well as positions and roles performed by the winning team. Overall, this article has elaborated the practices of democracy which does not flourish the democracy itself. 


\subsection{Postponement of Election Supervisory Committee (PANWASLU) Formation}

The weak function of the Supervisory Committee is one of the indicators of successful implementation of the local election as a form of local level democracy. The weakness of the supervisory function is mainly due to (i) a delay in the formation of PANWASLU, (ii) the regent is entitled to recruit the committee election district and (iii) the provision of operational budget of the district supervisory election by the local government.

The first factor that causes weak supervision of Supervisory Election Committee is through formation postponement. This is to describe the findings of the study with reference to the elections in Takalar in 2007 based on Law Number 32 of 2004 (Undang-Undang Nomor 32 tahun 2004) about Regional Government and Law Number 22 of 2007 (Undang-Undang Nomor 32 tahun 2004) about the Implementation of the General Election. Broadly speaking, the implementation of elections should go through three phases, namely: (i) preparation, (ii) the implementation and (iii) the completion stage. The rules can easily be overlooked by the authority of ruling government. It was found that PANWASLU was formed after a period of preparation. This is further worsened when supervision is not running and has entered the implementation phase. This stage is an important stage because the implementation phase is updating the voter data as well as registration of additional voters. As for some of the activities in the voters' updating data as well as voters' registration that did not come into play namely: (i) the delivery of the lists of potential voters from Election Commission (KPU) to the PPK, PPS all over Takalar, (ii) the submission of lists of potential voters by the Election Commission Takalar to PPK, PPS (iii) temporary list of voters by PPS, (iv) the announcement of the temporary list of voters by the PPS; (v) repairing of voter lists and voter registration as well as supplementary voter list by PPS; (vi) a release of supplementary voter list by PPS; (vii) approval and determination of improved voter list by the PPS; (viii) the announcement of the final voters list by PPS: (ix) preparation of a copy of the voters list by PPS; (x) preparation of the recapitulation of the number of voters registered by the Election Commission Takalar; (xi) preparation and recapitulation of registered voters by the Election Commission of Takalar.

Ideally, for election activities such as voters' registration and their improvement is the domain of supervisory, both the electoral supervisory of official institutions or other civil society groups. In contrast, the case of elections in Takalar was an important finding that all of the voters' registration processes were not under the supervision of PANWASLU Takalar. Moreover, this is evidence that the implementation of elections does not obey the State Rule of Law. These facts confirm the assessment by Baird (2012) who argued that the interaction between democracy and governance infrastructure is to be supported by obedience to the rule of law. Also the use of the power of incumbent to weaken the electoral supervisory body is one tactic that can undermine democracy by thinking Bryan and Baer (2005) who explained that the elections are using illegal tactics to win the competition.

Weak supervision as evident in the early stages of the elections has caused the occurence of some of the violations as in the case of a recount in the village of Patani. PANWASLU has committed a fraud through Bostan Tika who had close relations with Ibrahim Rewa (Incumbent Regent). He did vote twice, namely at polling stations (TPS) Sombala Bella Village and Village Patani. This is a form of omission by the Commission of Voting staff (KPPS) in the two villages. The main cause of this was the mistake of KPPS in listing the permanent voters (DPT) in the two villages. This violation of the weaknesses of DPT can be minimized through supervisory function that was run by PANWASLU Takalar. Unfortunately, as stated earlier the stewardship voter registration (DPT) cannot be implemented because the agency has not yet formed and this may lead to election criminal and injustice. Violations of election administration in Takalar were borned by the Commission (KPU). In this case, as many as 350 voters demonstrated at the polling station of Patani Village. The unfolding of these fraudulent practices provide insight that is consistent with the study of La Venia (2011) who reported that the incumbent generated unfair elections for the challengers.

The second factor, namely recruitment for the personnel of District PANWASLU is determined by the Regent Takalar. PANWASLU Takalar does not have the authority to position their staff at PANWASLU district level which was decided by Decree Takalar. Each PANWASLU district employed three civil servants. Overall employee is a person close to the incumbent. This has weakened the monitoring functions at the district level. For this case the distribution of rice to the poor at the village Pabundukang is clear evidence in PANWASLU district. Two days before the election, rice was distributed to the poor by Daeng Tutu. He was also a village of Pabundukang. Rice for the poor was labelled with stickers using the name of Golkar party and was distributed under the name of regency's candidate Ibrahim Rewa-A.Makmur. However, the case was immediately reconciled due to the fact that it was found by the district PANWASLU of South Polombangkeng sub district.

The third factor is the operationalization of institutional financing PANWASLU district and sub-district PANWASLU from the regional Budget (APBD) of Takalar 2007. The amount was only for Rp 400,000,000 
(equivalent to 40,000 USD) for all activities by PANWASLU Takalar and the other seven districts. In addition, the financial accountability was through Takalar Local Government, and was not through the General Board of Election Supervisors at the provincial or national level. This is another clear evident of the strong weakness of the PANWASLU supervisory. Thus the explanation of the second and third factors above suggest that neutrality of organizing Electoral Supervisory was too easily interfered by the ruling officials in order to win the competition so that the study by Dahl (1989) was in agreement with that of officials originally elected through free and fair elections.

\subsection{The Incumbent de Factor Power}

Takalar elections were held on $5^{\text {th }}$ November 2007 which was followed by four pairs of candidates. The pairs were sorted accordingly to the serial number of elections namely Hasanuddin Tisi-Nashar Baso and promoted by the joint parties like PPP, PBSD, PPD, PBR, PPNU, PKPB, PKB and PDIP; Ibrahim Rewa and A. Makmur Sadda carried Golkar party; Burhanuddin Baharuddin and Syamsari Kitta carried by PNBK, PAN, Merdeka Party, PKS, Pelopor Party, PSI and PKPI, and partner Said Pammusu-Ikrar Kamaruddin and Pledge promoted by PDK Party Sponsorship does not guarantee the crowded party voting that much anyway. This is because couples Ibrahim Rewa and A. Sadda were only carried by one party (Golkar Party) has triumphed with the most votes in the election of 2007 as many as 60,353 votes. While other couples are carried by some parties it lags far; Burhanuddin Baharuddin and Syamsari Kitta only obtained 34,829 votes, a couple and Nashar Baso and Hasanuddin Tisi obtained 29,618 votes and even couples Said Pammusu-Ikrar Kamaruddin and Pledge only get 16,844 votes.

How did it happen? The assumption was the more party result in more votes. The reality was not. One undeniable fact was Ibrahim Rewa in Takalar had a charisma, so big that one individual was able to bring down the domination of the party. Ibrahim's charisma could be tracked a long way back from his organizational history. This experience was also his prime asset for Ibrahim developing his charisma and image in Takalar, thus explained why Ibrahim Rewa was bold enough to compete in the previous Takalar's election (2002-2007). At that time, the selection of the Regent was not held directly, but conducted through the election by Takalar legislators. In 2002, Ibrahim Rewa did not win as easily as where in the elections of 2007. This is because of the thin victory Ichsan Yasin Limpo competitors who only two votes-that is, to go through the second round. When Ikhsan Yasin Limpo at that time was a member of parliament in South Sulawesi (period 1999-2004) and is the younger brother of the Vice Governor of South Sulawesi, Syahrul Yasin. Currently, Syahrul served as Governor of South Sulawesi for the period 2008-2013. While Ichsan Yasin Limpo, today, he is a Gowa regent for the second time until 2015.

In addition, his close relationship in the provincial level with the governor of South Sulawesi (H.M. Amin Syam) who was also the head of DPD Golkar of South Sulawesi rendered Ibrahim Rewa next to invincible. How was that so? One thing for sure Ibrahim was a head of district who was both directly and indirectly had a base of mass spread all over sub districts area. Besides than that, close observation on the competitor in 2007 PILKADA (Hasanuddin Tisi, Said Pammussu and Burhanuddin Baharuddin) proved that they only have the sole power in the sub-district level where they lived. Take Hasanuddin for example, despite the fact that he was indeed the son of Takalar but he spent most of his career in Jakarta as a businessman. Beside, Hasanuddin was viewed as a hitchhiker of his father's name, a retiree colonel of the army and a figure in the community of Takalar. Other weakness of Hasanuddin as a candidate could be assessed from the financial angle. His stepping forward for the election was due to the financial support of Head of DPP Partai Persatuan Daerah, Oemar Sapta (well-known businessman who resides in Jakarta). Similar to Hasanuddin, Said Pammussu was tweedledum and tweedledee. Despite his former position as a District Assistant (Sekda) of Takalar, Vice Head of District, a former member of DPRD of Takalar and the chief of Partai Demokrasi Kebangsaan (also the best friend of the founder of PDK, Prof. Dr. Ryaas Rasyid), Said's hands did not reach further than Mangarabombang sub-district. This groundless electability was also present in Burhanuddin (biggest mass were in North Galesong and South Galesong). Therefore, the advantage of Ibrahim compared to other candidates was his well-known image by the voters in many sub-districts of Takalar District.

The same result came up when the question was directed to the candidates of vice sub district of each competitor-why would Ibrahim Rewa so unmatched? Nashar Baso paired with Hasanuddin Tisi, was known well but only as far as Galesong sub-district. It was because he was from the area. More than less the same thing with Syamsari Kitta (paired with Burhanuddin) and Ikrar (paired with Said); their bases went no further than sub-district of Pattallassang and sub-districts of Mangarabombang, sub-district of Mappakasunggu and sub district of Galesong. In fact, Ikrar was found out to be originally from Buginese ethnic (sub district of Bone) hence for the calculation of PILKADA District of Takalar did not represent the sense of "locals"-which was required implicitly in the 2007 PILKADA of Takalar District. 
Referring to the above configuration, the problem now is, how was Ibrahim Rewa can keep his position in 2007 PILKADA and what power and instrument he used to prevent the dominion? To answer the first question, a few previous paragraphs had provide the answer that as a Head of District, Ibrahim Rewa was directly or indirectly had mass base that spread in several sub districts. The second reason, as the chief of Golkar Takalar for 2004-2009 periods, he had full and strong support from caretakers of DPD II Golkar of Takalar District.

This showed that during the Golkar Convention on March $26^{\text {th }}, 2007$, it was declared that he paired with act Vice Head of District 2002-2007, Makmur Andi Sadda who was also the head of Kosgoro of Takalar to come forward for PILKADA 2007 of Takalar. This couple was then known better an IRAMA during the campaign. IRAMA stood for Ibrahim RewA and MAkmur Sadda. Another indication of Ibrahim power to maintain the position in Takalar District was the participation from sub district level of Golkar caretaker in seven sub districts that declared their support for Ibrahim and ready to assist him in the succession as the Head of District of Takalar for the period of 2007-2012.

\section{Discussion}

The development of the concept and theory of democracy bear some views ahead by Dahl (1989), namely the role of democratic institutions to lean normative democratic process called polyarchy with the following characteristics: (i) control over government decisions are hidden through the constitutionally elected officials, (ii) elected officials through periodical free and fair elections, (iii) the practice of all adults to have the right to vote in the election, (iv) the practice of all adults to have the right to run in the election of officers, (v) citizens have the right to express freely in political issues, (vi) alternative sources of legal information that can freely be found, (vii) any person has the right to form parties, pressure groups, and independent state.

To criticize the lean concept of democratic institutions, Dahl (1989) viewed that one function of the political parties is to promote democracy. For this subject, it is pertinent to look back at the results of the role of political parties that fought to get the number of voters which is often stuck with the political practices carried out in various ways. Studies by Yadav (2012) on the 64 democratic countries in 1984-2004 found that the policy influence of political parties and the political elite corruption is a chronic problem faced in collecting enough money to pay for high-cost politics in a democracy. In addition, the study of political parties often use political tactics that are illegal to keep compete and prosper in politics seen in Bangladesh and Kenya. In addition, another scholar Bryan and Baer, $(2005$, p. 33) explained through their studies in 22 states that political parties use illegal election tactics include buying votes, hiring thugs to intimidate opponents, and filling the ballot boxes.

Discussion of the concepts of democracy and political power mentioned by Haugaard (2010) explained that democracy is a fragile flower that requires a special form of power and perception of authority. He explained that political power is the power that is conquered by the authority, based on the action taken. The authority requires a democracy that it contained about equality norm, the norm of balance, orderly, responsible. For the term of political power here will discuss specific incumbent by some research scholars. As performed by Gordon and Landa (2009) examined the incumbent taking into useful resources for him or better known as the "discount campaign." This has an impact for a smaller fee for the return fight. Compared with the challenger over increasing costs for the campaign, and the support of incumbent raises unique advantage with the ability to engage with interest groups or elites within a district. Discussion regarding advantages of the incumbent is similar to other reviewer, such as Weisberg (2002) in the United States. Competition is the American president of the Democratic Party and the Republican challenger. There are advantages: (i) political sluggishness: voters tend to vote for the incumbent that are relevant to the adage "If isn't a broke, do not fix it", (ii) can learn from the experiences of the previous election campaigns cost success, political work anything during his tenure, and repair mistakes to compete again, (iii) the incumbent was able to unite the parties, so that the challenger difficulty repairing cracks at election time, and (iv) able to control every event, stimulate the economy, and be able to control the agenda, (v) must be able to campaign without campaigning "The Rose Garden Strategy", (vi) claims that it is the candidate that is able to pass the changes.

Another similar study is concerned with the quality of the incumbent achievements in building democracy in the Philippines those locus 48 cities and counties during the period June 2004-June 2008. Research looks at competence of the incumbent (age, educational background), to re-fight status, and tenure. His finding concerns about existence of local innovation through the growth of local financial resources. As for other factors that affect the performance of the incumbent prior work by considering the level of poverty and the achievement of performance of public administration services (Capuno, 2011). In contrast, research on the difficulty of incumbent to be in power again by Lazarus (2008) in all U.S. states for the gubernatorial elections starting in 1976-1998. He got pervassive criticism during his tenure. It was the impact on the challenger to enter the competition. 
Referring to the various realities in the 2007 Takalar Election, the concept of democracy by some scholars was found to be an aberrant practice. Democracy is only used as a mount to legitimizing power of incumbent officials in maintaining power. Incumbent utilize the position and role of the central bureaucracy. Civil servants involved in several of the winning team. Furthermore, the independence of the election and the weakness of civil society oversight resulted in the decline of democracy in Takalar.

The instruments used by Ibrahim to maintain his dominion in PILKADA 2007 was to take advantage from central role and position of bureaucrats. As head of district, Ibrahim Rewa could easily utilized bureaucrats as his core team for the succession in PILKADA. His leader of succession team was Drs. Syarifuddin Hamzah, Chief of Public Relation Department, his background employees of the Ministry of Information. Under Chairman Winning Team Winning Team Management are played in multiple layers starting from the core team, Team Family and Local Government Unit Team (SKPD). All teams move in order to win the 'IRAMA' absolutely. A study by Gordon and Landa (2009) reported that the incumbent used a variety of resources, one of which is government officials to maintain its power, either for a position, or other positions. Secondly, there was an intervention of the appointment of members of PPK, PPS, KPPS and PANWASLU prior to PILKADA. This was due to the system that candidate members of PPK, PPS, KPPS can only be purposed through head of sub district and head of village. The result was PPK, PPS and KPKS tended to lean on the incumbent. In this case the competition became not health and the principles of democracy as suggested by Dahl (1992) such as the presence of democratic institution in performing the election and the free and just election were failed to comply. Moreover, incumbent innocently often utilizes infrastructure of village government such as making it the secretariat (the whole secretariat of PPK used a room of sub district main office and PPS secretariat used the village's office). The downside was, neutrality of PILKADA committee was then questionable.

Similar to PPK, PPS and KPPS, PANWASLU's independency also called into doubt. Why was it so? This was several cases were let unpunished by the PANWASLU such as: (i) the ballot that was hidden by Paramangta head of village (North Galesong Sub District) over 120 ballots; (ii) three days to the PILKADA, Ibrahim Rewa was allowed to distribute Raskin for the people despite of the calm period and such things. However, IRAMA did indeed work hard for it. For example, IRAMA did the best to provide the free medical facilitation, distributed accommodation to all mosques in the Friday safari tour through Bantuan Sosial mesjid (Social Welfare Department), conducted sport events such as volley competition (Ibrahim Rewa Cup which was held by group of Vespa Takalar SOG 777) and others. They paid off and IRAMA was re-elected to be the Head and Vice District of Takalar 2007-2012. This fact is in line thought Haynes (2001) about the lack of control, played by civil society.

Having being re-elected as the Head of District of Takalar, Ibrahim Rewa performed a massive reformation in his cabinet. Those who shared the same goal during PILKADA got promoted and those who opposed were demoted. This was a common thing for a government post PILKADA. Those in service during the succession will be awarded strategic positions, while those who oppose will be 'grounded'. It was a shame that the placement of the supporter was full with nepotism and not based on competence.

\section{Conclusion}

This study concludes that the incumbent has always been taking the advantages of the current power and authority in the postponement of the PANWALSU Takalar. This leads to a violated and unauthorized appointment of PANWASLU district officials in the upcoming general elections. In addition, the incumbent tends to overrule the government officials where this should not be happening in a local general election committee process.

\section{References}

Baird, R. G. (2012). Unpacking Democracy and Governance: Conceptualizing Governance Infrastructure. Social Science Information, 51(2), 263-279. http://dx.doi.org/10.1177/0539018412437112

Bryan, S., \& Baer, D. (2005). Money in politics: A study of party financing practices in 22 countries. National Democratic Institute for International Affairs. Washington DC.

Bunce, V. (2000). Comparative Democratization: Big and Bounded Generalizations. Comparative Political Studies, 33(6/7), 703-734. http://dx.doi.org/10.1177/001041400003300602

Capuno, J. J. (2011). Incumbents and Innovations under Decentralization: An Empirical Exploration of Selected Local Governments in the Philippines. Asian Journal of Political Science, 19(1), 48-73. http://dx.doi.org/10.1080/02185377.2011.568243

Crouch, H. (2010). Political Reform in Indonesia after Soeharto. Institute of Southeast Asian Studies. Singapore.

Dahl, R. A. (1989). Democracy and Its Critics. Yale University Press. New Haven and London. 
Dahl, R. A. (1992). Demokrasi dan Para Pengkritiknya. Yayasan Obor Indonesia. Jakarta (In Indonesian).

Erb, M., \& Sulistiyanto, P. (2009). Deepening Democracy Indonesia? Direct Elections for Local Leaders (PILKADA). Institute of Southeast Asian Studies. Singapore.

Gordon, S. C., \& Landa, D. (2009). Do the Advantages of Incumbency Advantage Incumbents? The Journal of Politics, 71(4), 1481-1498. http://dx.doi.org/10.1017/S0022381609990223

Haugaard, M. (2010). Democracy, Political Power and Authority. Social Research: An International Quarterly, 77(4), 1049-1074.

La Venia, P. A. Jr. A. (2011). Breaking the Iron Law: Robert Michels, the Rise of the Mass Party, and the Debate over Democracy and Oligarchy. Dissertation. The University at Albany, State University of New York, Rockefeller College of Public Affairs and Policy Department of Political Science.

Lazarus, J. (2008). Incumbent Vulnerability and Challenger Entry in State-wide Elections. American Politics Research, 36(1), 108-129. http://dx.doi.org/10.1177/1532673X07300908

Schumpeter, J. (2003). In R. A. Dahl, I. Shapiro, \& J. A. Cheibub (Eds.), Capitalism, Socialism and Democracy. The Democracy Sourcebook. Cambridge, MA: MIT Press.

Vanhanen, T. (1997). Prospect of Democracy a Study of 172 Countries. Routledge, London and New York.

Weisberg, H. F. (2002). Partisanship and incumbency in presidential elections. Political Behavior, 24(4), 339-360. http://dx.doi.org/10.1023/A:1022558810957

Yadav, V. (2012). Legislative Institutions and Corruption in Developing Country Democracies. Comparative Political Studies, 45(8), 1027-1058. http://dx.doi.org/10.1177/0010414011428596

\section{Copyrights}

Copyright for this article is retained by the author(s), with first publication rights granted to the journal.

This is an open-access article distributed under the terms and conditions of the Creative Commons Attribution license (http://creativecommons.org/licenses/by/3.0/). 